\title{
PARP1 wt Allele
}

National Cancer Institute

\section{Source}

National Cancer Institute. PARP1 wt Allele. NCI Thesaurus. Code C51001.

Human PARP1 wild-type allele is located within 1q41-q42 and is approximately $47 \mathrm{~kb}$ in length. This allele, which encodes poly [ADP-ribose] polymerase 1 protein, plays a critical role in DNA repair. 